\title{
PENERAPAN EVALUASI PEMBELAJARAN DALAM PEMBELAJARAN JARAK JAUH
}

\author{
Indra Bagus Dermawan ${ }^{1 *}$ \\ Sri Harmianto ${ }^{2}$ \\ 1,2Universitas Muhammadiyah Purwokerto, Purwokerto, Indonesia \\ indrabagusdermawan94@gmail.com ${ }^{1 *}$ ) \\ bimskripsi.srihar@gmail.com ${ }^{2}$
}

\begin{abstract}
Abstrak
Penelitian ini bertujuan untuk mendeskripsikan pelaksanaan evaluasi pembelajaran pada pembelajaran jarak jauh di SD Negeri 3 Purbalingga Lor. Penelitian ini menggunakan metode kualitatif deskriptif. Subjek pada penelitian ini meliputi kepala sekolah, guru, dan siswa SD Negeri 3 Purbalingga Lor. Uji keabsahan data pada penelitian ini menggunakan triangulasi sumber dan triangulasi teknik. Teknik pengumpulan data menggunakan wawancara, observasi, dan dokumentasi. Teknik analisis data pada penelitian ini yaitu dengan mengumpulkan data, reduksi data, display data, dan kesimpulan. Hasil penelitian menunjukan bahwa evaluasi pembelajaran yang meliputi penilaian pengetahuan, keterampilan, dan sikap tetap dijalankan, akan tetapi hasil yang ditunjukan kurang memuaskan karena tidak berjalan dengan maksimal seperti dalam penilaian pengetahuan masih banyak penilaian yang diberikan dikerjakan oleh orangtua/keluarga, dan sikap karena guru tidak bisa mengamati secara langsung, akan tetap dalam penilaian keterampilan guru merasa cukup lewat hasil yang memuaskan ditujukan oleh siswa meskipun beberapa masih terdapat kendala. Kendala dalam evaluasi pembelajaran jarak jauh yaitu adanya bantuan berlebih dari orang tua/keluarga dalam penilaian siswa, keterbatasan yang dimiliki wali murid dan smartphone yang dimiliki, siswa kesulitan memahami materi, guru kurang menguasai penilaian jarak jauh, tidak bisa mengamati langsung siswa. Solusi yang dilakukan guru untuk mengatasi kendala dalam evaluasi pembelajaran ialah membandingkan dengan hasil luring, melakukan tes lisan ketika pembelajaran, menjelaskan kembali materi, bantuan pemerintah, melakukan percobaan seperti menggunakan Quizizz.
\end{abstract}

Kata Kunci: Evaluasi Pembelajaran, Pembelajaran Jarak Jauh

Published by:

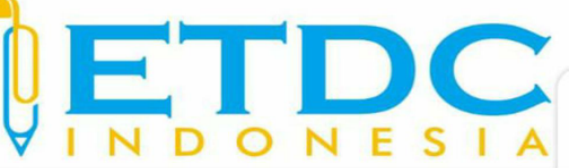

Copyright (C) 2021 The Author (s)

This article is licensed under CC BY 4.0 License (cc) $\mathrm{BY}$ 


\section{PENERAPAN EVALUASI PEMBELAJARAN DALAM PEMBELAJARAN JARAK JAUH}

\section{Pendahuluan}

Dunia pada saat ini sedang terserang virus yang bernama COVID-19. COVID-19 ini sendiri merupakan penyakit yang membuat penderitanya dapat mengalami sakit dengan gejala rendah maupun tinggi. COVID-19 atau Coronanirus Diseases 19 adalah penyakit yang belum lama ini baru ditemukan yang dapat menyebabkan gangguan pernapasan yang sangat berbahaya. Menurut Yulianto, Ahmad (2020) menyebutkan bahwa ciri dan gejala kebanyakan orang yang terinfeksi COVID-19 antara lain gejala gangguan pernafasan akut seperti demam, batuk dan sesak nafas.

Pendidikan terkena dampak yang begitu besar dengan adanya virus covid ini. Menteri Pendidikan dan Kebudayaan memberikan surat kepada sekolah dalam Surat Edaran Nomor 4 Tahun 2020 yang mengatur tentang segala pelaksanaan aktifitas pembelajaran pada masa rawan saat ini. Isi Surat Edaran yang diberikan tersebut menjelaskan bahwa pendidikan dilaksanakan pada tempat tinggal masing masing menggunakan pembelajaran jarak jauh yang bertujuan guna mengurangi persebaran virus ini semakin meluas. Selain itu juga memberikan pembelajaran kepada siswa pembelajaran yang bermakna.

Pembelajaran jarak jauh merupakan suatu pembelajaran yang dalam pelaksanaanya baik guru maupun siswa saling berjauhan satu dan lainnya, dengan memanfaatkan smartphone untuk dijadikan alat dalam berintraksi antara guru dan siswa yang berada di tempat tinggal masing indivdu. Menurut Rizal dalam Iqbal Faza Ahmad (2020) menjelaskan bahwa pembelajaran jarak jauh merupakan pembelajaran yang dilaksanakan dengan jarak jauh bukan bertemu secara langsung. Komunikasi yang dilaksanakan dua arah menggunakan fasilitas yang sudah tersedia seperti telepon, video, internet, dan lainnya. Tertujuan dilaksanakannya pembelajaran jarak jauh ini untuk menghindari kerumunan yang terjadi di lingkungan sekolah yang dapat meningkatkan resiko siswa siswi maupun guru dan karyawan terkena virus covid ini.

Penerapan Pembelajaran Jarak Jauh (PJJ) memberikan pengalaman baru bagi guru maupun siswa dalam melaksanakan pembelajaran. Pembelajaran yang biasanya dilaksanakan dengan tatap muka, pada saat sekarang ini dituntut untuk melaksanakan pembelajaran jarak jauh. Tentu saja pada penerapannya, pembelajaran ini masih mengalami kesulitan hal ini dikarenakan kurangnya persiapan dari pihak sekolah maupun pemerintah dalam pelaksanaan. Oleh karena itu guru perlu mengevaluasi pembelajaran yang sudah dilaksanakan guna memperoleh informasi serta kekurangan yang dialami untuk segera diperbaiki. 
Evaluasi pembelajaran merupakan rangkaian penilaian yang dilaksanakan oleh guru selama pembelajaran berlangsung. Menurut Haryanto (2020) menerangkan bahwa evaluasi pembelajaran merupakan usaha untuk mengetahui sejauh mana pembelajaran yang sudah dilaksanakan bisa berjalan dengan maksimal sehingga berdasarkan hasil tersebut nantinya bisa dijadikan bahan perbaikan dan pengembangan pembelajaran agar dapat berjalan dengan efektif dan efisien. Adanya kesimpulan dalam setiap akhir pembelajaran mempermudah guru dalam menentukan langkah selanjutnya untuk pembelajaran yang ia laksanakan.

Melalui pengamatan awal peneliti, penilaian pembelajaran yang dilaksanakan di SD Negeri 3 Purbalingga Lor pada pembelajaran jarak jauh baru menggunakan tes berupa soal yang diberikan kepada siswa melalui aplikasi Whatsapp. Dalam pelaksaananya guru memberikan soal kepada siswa, lalu siswa diberikan waktu untuk mengerjakan selama beberapa hari dan dikumpulkan ke sekolah secara pribadi atau keluarga sebagai perwakilannya untuk mengumpulkan. Pihak sekolah juga telah menyediakan tempat khusus untuk pengumpulannya berupa meja untuk meletakan hasil kerja siswa yang telah diberikan dari masing masing kelas yang bertujuan untuk mengurangi kontak langsung.

Adanya pembelajaran jarak jauh mengakibatkan semua aktivitas pembelajaran dilaksanakan di rumah masing masing, begitu pun dengan pelaksanaan evaluasi pembelajaran. Akan tetapi yang menjadi permasalahannya yaitu apakah pelaksanaan evaluasi pembelajaran yang diberikan oleh guru dapat berjalan dengan lancar, sesuai dengan ketentuan, dan dikerjakan dengan jujur oleh siswa ataukah tidak. Hal ini menjadi permasalahan karena evaluasi pembelajaran berguna bagi guru untuk mengetahui capaian belajar siswa, dan apabila tidak berjalan dengan semestinya maka akan mengakibatkan pembelajaran berikutnya tidak efektif dan maksimal. Mengingat ketika pembelajaran jaraka jauh guru tidak mengawasi siswa dalam evaluasi pembelajaran yang diaksanakan.

\section{Metode Penelitian}

Penelitian ini merupakan jenis penelitian kualitatif deskriptif dimana yang mana subjek penelitian meliputi kepala sekolah, 7 guru, dan 7 siswa. Penelitian ini dilakukan di SD N 03 Purbalingga Lor yang terletak di Kecamatan Purbalingga Lor. Teknik pengumpulan data dilakukan dengan cara wawancara, observasi, dan dokumentasi. Peneliti berperan sebagai pewawancara langsung untuk menggali data melalui kepala sekolah, guru, dan peserta didik. Langkah-langkah yang dilakukan oleh peneliti yaitu mengumpulkan data, reduksi data, penyajian data, dan menyimpulkan data. 


\section{Hasil dan Pembahasan}

\subsection{Pelaksanaan evaluasi pembelajaran pada pembelajaran jarak jauh}

Pelaksanaan evaluasi pembelajaran yang dilaksanakan di SD Negeri 3 Purbalingga Lor tetap dilaksanakan. Meskipun pembelajaran yang dilaksanakan dengan jarak jauh yang bertujuan untuk mengurangi kerumunan di sekolah, evaluasi pembelajaran tetap dilaksanakan seperti biasa sesuai dengan Kompetensi Inti dari pembelajaran. Hal tersebut sesuai dengan penjelasan Astuti dalam Muhammad Fitrah dan ruslan (2021) pelaksanaan evaluasi ialah inti dari pelaksanaan pendidikan dan suatu keharusan untuk dilakukan serta menjadi catatan penting guna memetakan capaian siswa pada proses pembelajaran dan memperoleh feedback bagi siswa.

Pelaksanaan evaluasi pembelajaran jarak jauh tentu dengan menyesuaikan keadaan yang dihadapi sama seperti pembelajaran yang dilaksanakan lewat jarak jauh. Seperti penilaian pengetahuan yang guru laksanakan dengan memberikan soal lewat aplikasi, penilaian keterampilan yang dilaksanakan di rumah dan hasil dikumpulkan lewat whatsapp, dan penilaian sikap dilaksanakan dengan cara pengamatan guru dari keaktifan siswa. Hal tersebut sesuai dengan pendapat Muhammad Fitrah dan ruslan (2021) menyebutkan bahwa guru secara umum menggunakan aplikasi Whatsapp sebagai sarana penyampaian soal, latihan, dan ulangan.

Penilaian pengetahuan tetap dilaksanakan oleh seluruh guru yang berada di SD Negeri 3 Purbalingga Lor pada saat pembelajaran jarak jauh. Guru melaksanakan penilaian jarak jauh dengan cara memberikan tugas melalui whatsapp group dengan memberikan intruksi untuk mengerjakan tugas pada buku tema yang dimiliki siswa. Selain itu guru juga menggunakan google form untuk penilaian, dan juga guru terkadang menggunakan website yang sudah ada guna melakukan penilaian dalam penilaian yang dilaksanakan.

Melalui penilaian pengetahuan yang dilaksanakan, memunculkan hasil yang bervariasi. Guru yang ada di SD Negeri 3 Purbalingga Lor memberikan keterangan bahwa hasil penilaian pengetahuan jarak jauh belum memenuhi harapan dari guru. Setelah melaksanakan penilaian guru merasa belum bisa mendapatkan gambaran dari penilaian yang dilaksanakan siswa terkait materi yang diajarkan. Hal tersebut dikarenakan adanya berbagai faktor. Faktor yang paling besar membuat guru tidak bisa mendapatkan gambaran capaian siswa secara maksimal dikarenakan adanya bantuan yang diberikan oleh orang tua/keluarga yang berlebihan sehingga hasil penilaian yang dikerjakan tidak murni dari pemahaman siswa. Hal tersebut tidak sesuai dengan surat edaran Permendikbud nomor 719 tahun 2020 tentang Pedoman Pelaksanaan Kurikulum pada Satuan Pendidikan dalam kondisi khusus, pada pembahasan Asesmen dalam kondisi khusus ayat (1) menyebutkan Valid yaitu Asesmen menghasilkan informasi yang sahih 
mengenai pencapaian peserta didik.

Faktor yang melatar belakangi orang tua/keluarga untuk melakukan hal tersebut yaitu dikarenakan siswa yang bermasalah, ketakutan kepada anaknya apabila tidak lulus maupun tinggal kelas, ataupun agar siswa cepat selesai. Akan tetapi ada sebagian guru yang merasa sudah puas dengan hasil yang didapatkan. Hal tersebut dikarenakan guru sudah mempunyai bekal dari pembelajaran tatap muka yang dulu pernah dilaksanakan sehingga guru mempunyai gambaran akan kemampuan masing-masing peserta didiknya.

Penilaian keterampilan pada pembelajaran jarak jauh tetap dilaksanakan sesuai dengan kompetensi inti yang ada. Menurut Syahruddin Damanik dkk. (2020) menyebutkan bahwa Evaluasi berbasis praktik mengharuskan siswa untuk mempraktikan gerakan gerakan yang diberikan. Hal tersebut mengingat adanya kompetensi pembelajaran yang menghendaki adanya aspek psikomotorik. Pelaksanaan keterampilan dengan cara guru memberikan tugas untuk membuat karya atau untuk melakukan sesuatu dan direkam lalu dikumpulkan kepada guru. Dalam pelaksanaannya terkadang guru juga membuat siswa secara berkelompok sesuai dengan teman dekat rumahnya.

Melalui pemaparan yang diberikan narasumber, dapat disimpulkan bahwa penilaian keterampilan pada pembelajaran jarak jauh berjalan dengan maksimal. Hasil penilaian keterampilan sangat memuaskan bagi guru, hal tersebut dikarenakan siswa memang senang apabila diberikan tugas praktek, dan juga menurut pemaparan narasumber juga diketahui bahwa siswa senang apabila mengerjakan tugas prakteknya bersama teman teman lainnya. Hal tersebut juga sesuai dengan pengamatan yang dilakukan peneliti bahwa hasil penilaian keterampilan dapat dilihat di sekolah yang menunjukan hasil yang memuaskan. Akan tetapi dalam penilaian keterampilan dibeberapa kelas juga mengalami kendala. Kendala yang dihadapi sama seperti penilaian pengetahuan yaitu tugas yang diberikan oleh guru dikerjakan oleh orang lain sehingga tidak bisa mengukur pemahaman siswa terkait materi yang diberikan

Penilaian sikap pada pembelajaran jarak jauh juga dilaksanakan sesuai dengan kompetensi inti pada pembelajaran. Dalam pelaksanaannya guru mengamati siswa melalui tugas yang diberikan dan juga melalui keaktifan siswa dalam mengikuti pembelajaran jarak jauh yang dilaksanakan oleh guru. Hal tersebut sesuai dengan pendapat dari Susilawati dan Syaripah (2019) menyebutkan bahwa Penilaian sikap ini bukan merupakan penilaian yang terpisah dan berdiri sendiri, namun merupakan penilaian yang pelaksanaannya terintegrasi dengan penilaian pengetahuan dan keterampilan, sehingga bersifar autentik. Selain itu guru juga berkerja sama dengan orang tua siswa untuk melaporkan mengenai sikap siswa ketika pembelajaran di rumah. 
Berdasarkan data yang diperoleh, penilaian sikap merupakan penilaian yang membuat guru kesulitan dalam melihat gambaran capaian siswa dalam capaian belajar terkait tingkah laku hal tersebut berdasarkan pemaparan yang diberikan oleh narasumber. Sebagian guru merasa kurang puas karena penilaian sikap dalam pelaksanaannya sangatlah terbatas. Menurut pemaparan dari narasumber menyebutkan bahwa penilaian sikap sejatinya dilaksanakan dengan cara mengobservasi siswa di dalam kelas selama pembelajaran dilaksanakan oleh guru. Karena pembelajaran dilaksanakan dengan jarak jauh, guru tidak bisa melaksanakan hal tersebut. Meskipun pelaksanaan penilaian sikap tetap dilaksanakan dengan cara observasi siswa lewat online dan dari laporan orang tua, tetapi tetap guru belum merasa puas dari hasil yang didapatkan karena tidak bisa dilihat dan dirasakan oleh guru.

Keterbatasan dalam memperoleh data guna dijadikan bahan penilaian oleh guru menjadikannya kurang puas, bahwa penilaian sikap belum bisa memberikan gambaran mengenai capaia belajar siswa. Akan tetapi sebagian guru merasa puas dengan hasil yang didapatkan. Hal tersebut dikarenakan guru sudah mempunyai bekal terkait gambaran siswa ketika pembelajaran tatap muka sehingga bisa dijadikan gambaran mengenai sikap siswa dalam mengikuti pembelajaran.

\subsection{Kendala guru dalam menyusun perangkat evaluasi pembelajaran pada pembelajaran jarak jauh.}

Kendala yang dialami guru ketika melaksanakan evaluasi pembelajaran jarak jauh di SD Negeri 3 Purbalingga Lor yaitu adanya bantuan yang berlebih dari orang tua. Bantuan yang diberikan oleh orang tua tentu tidak menjadi masalah apabila masih dalam batas wajar. Akan tetapi apabila orang tua membantu siswa dengan mengerjakan tugasnya tentu akan membuat guru kesulitan dalam mendapatkan gambaran mengenai pemahan siswa akan materi yang diajarkan. Banyak hal yang mendasari orang tua melakukan hal demikian, diantaranya yaitu ketakutan orang tua apabila anaknya tidak naik kelas atau tidak lulus, agar anak berhenti menangis, dan lainnya. Tentu hal ini menjadi kendala yang berat bagi guru karena guru akan kesulitan mengidentifikasi pemahan siswa akan materi yang diajarkan.

Keterbatasan yang dimiliki oleh wali murid juga menjadi kendala bagi guru. Ketika mengerjakan tugas terkadang smartphone siswa mengalami permasalahan seperti memori penuh dan apabila untuk memperbaharui dengan yang baru akan sangat sulit karena tidak semua orang tua berkecukupan. Selain itu di SD Negeri 3 Purbalingga Lor masih banyak siswa yang menggunakan handphone milik orang tuanya sehingga pembelajaran mengikuti kesanggupan orang tua. Kebanyakan orang tua yang anaknya disekolahkan di SD Negeri 3 Purbalingga Lor memiliki perkerjaan sebagai buruh pabrik yang mana setiap pulang kerja di waktu malam. 
Sehingga siswa bisa mengerjakan tugas ketika malam hari. Hal ini tentu membuat sulit guru dalam melaksanakan evaluasi dari lamanya guru mengolah data karena menunggu siswa yang belum mengumpulkan, dan juga menentukan strategi apa yang tepat agar siswa mampu mengikuti pembelajaran jarak jauh yang optimal.

Berdasarkan data yang diperoleh, kesulitan siswa dalam memahami materi juga menjadi kendala bagi guru dalam pelaksanaan evaluasi pembelajaran. Berdasarkan hasil yang didapatkan, siswa terkadang merasa kesulitan dalam memhamai materi yang diajarkan, sehingga hal ini tentu berdampak pada siswa yang kesulitan dalam mengerjakan tugas. Akan tetapi siswa justru tidak menyampaikan keluhannya kepada guru karena siswa beralasan merasa malu. Hal ini tentu membuat guru kesulitan dalam melaksanakan evaluasi pembelajaran. Yang mana apabila dibicarakan kepada guru, maka guru bisa langsung mengidentifikasi kesulitan tersebut sehingga bisa dicarikan jalan kelaurnya. Apabila tidak dibicarakan tentu akan membuat guru kesulitan dalam melaksanakan evaluasi pembelajaran. Hal ini juga bisa memicu adanya bantuan dari orang tua/keluarga untuk memabntu siswa dnegan cara mengerjakannya karena siswa kesulitan dalam memahami materi.

Keterbatasan yang dimiliki oleh guru juga menjadi kendala. Keterbatasan pengetahuan guru terkait pembelajaran jarak jauh menjadi kendala pula dalam pelaksanaan evaluasi pembelajaran. Pada dasarnya keterbatasan yang dimiliki guru dikarenakan pelaksanaan pembelajaran jarak jauh yang mendadak, dan juga karena guru kurang siap dalam menghadapinya. Hal tersebut diakui langsung oleh guru yang menjadi narasumber bahwa pemahaman guru dalam pembelajaran jarak jauh sangatlah kurang sehingga hal ini menjadi kendala. Seperti yang dijelaskan oleh narasumber bahwa guru sudah melaksanakan berbagai pembelajaran daring menggunakan whatsapp group, google meet, form, classroom, dan zoom akan tetapi masih kurang maksimal. Selain itu juga terkendala hal lainnya seperti keterbatasan orang tua siswa.

Menurut pemaparan guru menjelaskan bahwa tidak bertemu langsung dengan siswa sudah menjadi kendala yang berat dihadapi guru. Terkhusus pada penilaian sikap yang membutuhkan observasi. Pada penilaian sikap tentunya guru memberikan melaksanakan penilaian dengan mengobservasi siswa secara langsung, akan tetapi karena adanya pembelajaran jarak jauh hal ini tidak bisa diterapkan. Meskipun sudah dengan cara mengobservasi lewat keaktifan siswa mengerjakan tugas dan laporan dari orang tua, akan tetapi tetap hal ini tidak cukup memberikan gambaran dari siswa. Selain itu apabila dilaksanakan pembelajaran tatap muka apabila siswa yang kesulitan maka pada saat itu juga akan dibantu, akan tetapi hal ini berbeda ketika pembelajaran jarak jauh yang tidak bisa melaksanakan 
bantuan pada saat itu juga apabila kesulitan

\subsection{Solusi guru dalam menyusun perangkat evaluasi pembelajaran pada pembelajaran jarak jauh}

Solusi yang dilakukan guru untuk mengatasi kesulitan guru dalam mengidentifikasi terkait gambaran pengetahuan siswa apabila dibantu oleh orang tua/keluarga dalam mengerjakan tugasnya yaitu dengan melihat hasil pada saat pembelajaran tatap muka dulu dan observasi yang dilaksanakan guru pada saat itu. Pada awal pembelajaran sempat dilaksanakan pembelajaran tatap muka akan tetapi tidak berlangsung lama. Berdasarkan hasil tersebut dijadikan guru sebagai bekal untuk mengetahui akan tingkat pemahaman siswa terkait materi.

Tes lisan juga digunakan guru untuk dijadikan solusi dalam mengetahui pemahaman siswa akan materi yang difahami. Hal tersebut sesuai dengan Syahruddin Damanik dkk.(2020) menyebutkan bahwa Evaluasi berbasis lisan pada pembelajaran tatap muka jarang direapkan karena akan membuat siswa kesulitan, pada pembelajaran jarak jauh siswa diberi tugas oleh guru melalui whatsapp grup lalu siswa diminta menjawabnya dengan lisan. Tes lisan dilaksanakan pada saat pembelajaran dilaksanakan sepeti menggunakan zoom maupun google meet, yang mana nantinya guru akan memberikan kepada siswa secara acak mengenai materi yang kemarin diujikan. Melalui hal tersebut menurut pemaparan guru mendapatkan hasil yang sesuai harapan. Dimana siswa yang memang menmahami materi akan menjawab dengan benar, dan siswa yang tidak memahami materi juga tugas dikerjakan oleh orang tua akan kesuiltan menjawab. Sehingga tes lisan bisa menjadi opsi bagi guru untuk mendapatkan hasil yang sesuai dengan apa yang diharapkan.

Solusi yang guru lakukan untuk mengatasi kesulitan memahami materi yang dialami oleh siswa yaitu dengan enjelaskan kembali materi yang diajarkan. Apabila siswa masih kesulitan maka guru melaksanakan bimbingan secara langsung kepada siswa yang merasa kesulitan untuk memahami materi yang diajarkan. Siswa bisa datang langsung ke sekolah atau ke rumah guru yang mengajar di kelasnya. Selain itu juga guru bisa langsung datang ke rumah siswa untuk mengatasi kesulitan yang dialami. Hal ini tentu dengan protokol kesehatan yang sesuai sehingga tidak menyalahi aturan yang diberikan pemerintah terkait belajar mengajar.

Pemerintah atau dinas pendidikan juga ikut membantu guru untuk mencari cara guna melaksanakan penilaian pada jarak jauh. Bantuan yang diberikan ini dalam bentuk pelatihan bagi guru. Akan tetapi pelatihan ini baru dilaksankan pad guru kelas 6 saja. Hal ini dirasa karena guru kelas 6 menghadapi siswa yang akan melaksanakan ujian kelulusan sehingga diharapkan ujian tersebut bisa berjalan dengan lancar. Bagi guru lainnya direncanakan akan mendapatkan bantuan dari pemerintah dalam bentuk pelatihan pada tahun ajaran berikutnya yaitu pada tahun 
ajaran 2021/2022. Selain itu pemerintah juga memberikan bantuan kepada guru guru dalam bentuk subsidi kuota guna menunjang pembelajaran yang mana pembelajaran jarak jauh sendiri membutuhkan internet yang memadai sehingga perlu adanya kuota guna menjalaknannya.

Menggunakan website yang tersedia di internet juga dijadikan solusi untuk melaksanakan penilaian yang menyenangkan seperti contohnya Quizizz. Aplikasi ini dipilih karena dirasa oleh guru bisa menarik minat siswa untuk bersemangat dalam mengerjakan soal yang diberikan. Mengerjakan soal dalam quizizz seperti layaknya bermain game kuis, yang mana terdapat berbagai gamabr menari serta juga musik bagi anak merasa senang. Selain itu juga memudahkan guru karena bisa langsung mendapatkan nilai karena sudah dikoreksi oleh sistem. Penggunaan website Quizizz mendapatkan respon positif dari anak yang merasa senang mengikutnya, akan tetapi hal ini disayangkan karena jarang sekali pelaksanaannya. Hal ini tentu tidak terlepas dari kesibukan yang dimiliki guru sehingga tidak bisa menyiapkan Quizizz setiap saat bagi siswa.

\section{Kesimpulan}

Evaluasi pembelajaran di SD Negeri 3 Purbalingga Lor tetap dilaksanakan pada pembelajaran jarak jauh. Penilaian pengetahuan tetap dilaksanakan dengan hasil yang diperoleh oleh penilian tersebut masih dirasa kurang memuaskan. Penilaian keterampilan tetap dilaksankan dan hasil yang diperoleh guru merasa cukup puas karena siswa senang mengikuti penilaian keterampilan sehingga guru bisa mengidentifikasi capaian belajar siswa. Penilaian sikap pada pembelajaran jarak jauh tetap dilaksanakan dengan dengan hasil yang diperoleh guru merasa sangat kurang puas karena pada dasarnya penilaian sikap dilaksanakan dengan pengamatan langsung oleh guru sehingga mendapatkan hasil yang memuaskan.

Kendala kendala yang ditemui guru SD Negeri 3 Purbalingga Lor yaitu keikutsertaan orang tua/keluarga dalam mengerjakan penilaian siswa,. Keterbatasan orang tua dalam membimbing, membina, dan mengawasi siswa dirumah serta juga perekonomian keluarga. Siswa kesulitan memahami materi. Keterbatasan pengetahuan dan pengalaman guru pada pembelajaran jarak jauh juga menjadi kendala bagi guru. Tidak bisa bertemu dengan siswa sehingga tidak bisa mengawasi, membimbing, membina dan mengajarkan secara maksimal.

Solusi yang guru temukan dalam permasalahan pada pembelajaran jarak jauh yaitu guru menggunakan nilai serta pengamatan pada saat pembelajaran tatap muka,. Tes lisan, menjelaskan kembali materi kepada siswa bagi siswa yang masih merasa kesulitan, memanfaatkan website Quizizz untuk menambah pengalaman siswa dalam pembelajaran jarak jauh, bantuan dari pemerintah pelatihan pelatihan bagi guru pada pembelajaran jarak jauh. 


\section{DAFTAR PUSTAKA}

Haryanto. (2020). Evaluasi Pembelajaran (Konsep dan Manajemen). Yogyakarta: UNY Press.

Iqbal Faza Ahmad. (2020). Asesmen Alternatif Dalam Pembelajaran Jarak Jauh Pada Masa Darurat Penyebaran Coronavirus Disease (Covid-19) di Indonesia. Jurnal Pedagogik, 7(1), 195-122.

Fitrah, Muhammad dan Ruslan. (2021).Eksplorasi Sistem Pelaksanaan Evaluasi Pembelajaran di Sekolah Pada Masa Pandemi Covid-19 di Bima.Jurnal Basicedu, 5(1),178-187.

Susilawati dan Saripah. (2019).Analisis Pelaksanaan Evaluasi Pembelajaran Berbasis Tematik di Madrasah Ibtidaiyah Kabupaten Rejang Lebong.Jurnal Pendidikan Dasar, 3(1):1-22.

Syahruddin Damanik, Muhammad Zuhdi, Herlina Hazizah.(2020).Model Evaluasi Pembelajaran AUD Berbasis Daring di RA Nurun Namirah Medan Marelan. Jurnal Pendidikan dan Keislaman, 3(1), 155-172.

Yurianto, Ahmad, Bambang Wibowo, K. P.(2020).Pedoman Pencegahan dan Pengendalian Coronavirus Disease (COVID-19).2020.Kementrian Kesehatan RI Direktorat Jendral Pengendalian dan Pengendalian Penyakit. 